\title{
miR-21 inhibits autophagy and promotes malignant development in the bladder cancer $\mathbf{T} 24$ cell line
}

\author{
HUI-HUI ZHANG ${ }^{1}$, ZHONG-XIN HUANG ${ }^{1}$, SU-QUAN ZHONG $^{2}$, KUI-LIN FEI ${ }^{3}$ and YOU-HAN CAO ${ }^{1}$ \\ ${ }^{1}$ Department of Urology, The First Affiliated Hospital of University of South China, Hengyang, Hunan 421001; \\ ${ }^{2}$ Department of Urology, Yue Bei People's Hospital, Shaoguan, Guangdong 512025; ${ }^{3}$ Department of Obstetrics, \\ Xiangya Hospital, Central South University, Changsha, Hunan 410008, P.R. China
}

Received June 21, 2019; Accepted January 8, 2020

DOI: $10.3892 /$ ijo.2020.4984

\begin{abstract}
MicroRNA-21 (miR-21) is reported to exhibit cancer-promoting activity in various types of cancer. It has been previously demonstrated that miR-21 is overexpressed in bladder tumor tissue compared with normal mucosa. However, the functional mechanism of miR-21 in bladder cancer remains largely unknown. Thus, the current study aimed to determine the roles of miR-21 in autophagy and the malignant development of bladder cancer in T24 cells. Upregulation or downregulation of miR-21 was achieved following the transfection of miR-21 mimic or miR-21 inhibitor. An MTT assay was additionally performed to measure cell growth. Wound healing and transwell invasion assays were used to detect cell migration and invasion. The apoptotic potential and cell cycle were examined via flow cytometry and reverse transcription-quantitative PCR was performed to evaluate the expression of phosphatase and tensin homolog (PTEN), beclin 1, microtubule-associated protein 1 light chain 3B (LC3-II), cyclin D1, caspase-3, E-cadherin, matrix metallopeptidase-9 (MMP-9) and vimentin. The results revealed that the proliferation, migration and invasion of T24 cells was greatly increased in the miR-21 mimic group, while apoptosis was greatly inhibited. Additionally, T24 cells treated with miR-21 mimic exhibited G1-phase arrest. In the miR-21 mimic group, the expression of PTEN, beclin 1, LC3-II, caspase-3 and E-cadherin were decreased, while the expression of cyclin D1, MMP-9 and vimentin were increased. Opposite effects were observed in the miR-21 inhibitor group. The data of the current study may indicate that miR-21 overexpression inhibited autophagy and promoted the proliferation, migration, invasion and epithelial to mesenchymal transition of bladder cancer T24 cells. The
\end{abstract}

Correspondence to: Dr Hui-Hui Zhang, Department of Urology, The First Affiliated Hospital of University of South China, 69 Chuanshan Road, Hengyang, Hunan 421001, P.R. China

E-mail: jimmy.hui@163.com

Key words: microRNA-21, autophagy, proliferation, migration, invasion, epithelial-mesenchymal transition, bladder cancer results may further elucidate the molecular mechanism of miR-21 in the development of bladder cancer.

\section{Introduction}

Bladder cancer (BC) is one of the most common urinary tumors, with an increasing incidence worldwide every year (1). Although BC can be treated via transurethral resection, radical cystectomy and chemotherapy, it still has a high mortality rate due to its high incidence of metastasis (2). Thus, there is an urgent need to determine the underlying mechanism of $\mathrm{BC}$ development to improve the therapeutic outcome of patients.

MicroRNAs (miRNAs or miRs) are a class of small regulatory non-coding RNAs that serve important roles in many signaling pathways, including cell survival, apoptosis, cancer migration and cancer progression (3). Furthermore, an increasing number of miRNAs have been associated with the diagnosis and prognosis of certain types of cancer $(4,5)$.

The miR-21 gene is located on chromosome 17q23 (6). Previous studies have determined that miR-21 is upregulated and exhibits oncogenic activity in different types of cancer $(7,8)$. For example, the expression of miR-21 was increased in prostate cancer (9). miR-21 promotes the proliferation of oral cancer cells via tumor necrosis factor- $\alpha$ (10). Additionally, the expression of miR-21 markedly decreases following trastuzumab therapy in patients with EGFR2-positive metastatic breast cancer (11). The ratio of miR-21/24 is significantly correlated with several important prognostic factors in colorectal cancer, including tumor size, TNM stage, lymph metastasis and histologic differentiation (12). Furthermore, the ratio of miR-21/24 has been determined to be a significant survival risk factor for patients with colorectal cancer. The current study revealed that miR-21 overexpression was associated with recurrence and invasiveness in $\mathrm{BC}$ (13). However, the underlying mechanism of miR-21 in BC is remains largely unknown. The current study aimed to determine the role of miR-21 in the regulation of cellular phenotypes and its molecular mechanism in BC.

\section{Materials and methods}

Cell line and culture. The human bladder cancer cell line, T24, was obtained from the Cell Bank of Type Culture Collection of the Chinese Academy of Sciences. Cells were cultured in 
DMEM (Merck KGaA) with $10 \%$ fetal bovine serum (FBS; Gibco; Thermo Fisher Scientific, Inc.) and incubated in $5 \% \mathrm{CO}_{2}$ at $37^{\circ} \mathrm{C}$.

Transfection. To inhibit or overexpress miR-21 in BC cells, pGC-U6/Neo/GFP/miR-21 mimic, pGC-U6/Neo/GFP/miR-21 inhibitor and associated negative control (miR-21-NC) were obtained from Shanghai Gene Pharma Co., Ltd. A total of $3 \mu \mathrm{g}$ miR-21 mimic or inhibitor was transfected into BC cells using Lipofectamine ${ }^{\circledR} 2000$ (Invitrogen; Thermo Fisher Scientific, Inc.) according to the manufacturer's protocol. The sequences of the miR-21 mimic and miR-21 inhibitor were as follows: 5'-TAAACGGGCCCTCTAGACTCGAGT TATCAAATCCTGCCTGACTG-3' and 5'-GATCCTCAA CATCAGTCTGATAAGCTATTTTT-3', respectively. After $48 \mathrm{~h}$, cells were obtained for subsequent experiments. The following stably transfected T24 groups were established: miR-21 mimics group (mimics group), miR-21 inhibitor group (inhibitor group), negative control (NC) group and blank control (con) group without transfection.

Reverse transcription-quantitative PCR (RT-qPCR). Total RNA was extracted from T24 cells using TRIzol ${ }^{\circledR}$ reagent (Invitrogen; Thermo Fisher Scientific, Inc.). and reverse transcribed at $37^{\circ} \mathrm{C}$ for $60 \mathrm{~min}$ using the miDETECT A Track $^{\mathrm{TM}}$ miRNA qRT-PCR Starter kit (Guangzhou RiboBio Co., Ltd.). Subsequently, qPCR was performed using a SYBR Green kit (Takara Bio, Inc.) and an ABI PRISM 7500 Sequence Detection System (Applied Biosystems; Thermo Fisher Scientific, Inc.). The thermocycling conditions were as follows: $94^{\circ} \mathrm{C}$ for $3 \mathrm{~min}$; followed by 40 cycles of $94^{\circ} \mathrm{C}$ for $30 \mathrm{sec}$ and $72^{\circ} \mathrm{C}$ for $45 \mathrm{sec}$. The following primers were used: miR-21 forward, 5'-TAGCTTATCAGACTGATGTTGA-3' and reverse, 5'-TGGTGTCGTGGAGTCG-3'; U6 forward, 5'-GCT TCGGCAGCACATATACTAAAAT-3' and reverse, 5'-CGC TTCACGAATTTGCGTGTCAT-3'. RNA quantification was calculated using the $2^{-\Delta \Delta \mathrm{Cq}}$ method (14).

Western blot analysis. Cells were treated with RIPA lysis buffer (Beyotime Institute of Biotechnology) and centrifuged at $4^{\circ} \mathrm{C}$ for $10 \mathrm{~min}$ at $9,063 \mathrm{x}$ g to remove cell debris. After collecting the supernatant, a bicinchoninic acid protein assay (Beyotime Institute of Biotechnology) was used to detect protein concentration. Equal quantities of protein $(20 \mu \mathrm{g})$ were then added each lane for electrophoresis with $10 \%$ SDS-PAGE and subsequently transferred onto PVDF membranes (EMD Millipore). The membranes were blocked at $37^{\circ} \mathrm{C}$ for $3 \mathrm{~h}$ in a blocking solution consisting of Tris-buffered saline containing $0.1 \%$ Tween-20 and $5 \%$ bovine serum albumin (Sigma-Aldrich; Merck KGaA). Subsequently, the following primary antibodies were added and incubated overnight at $4^{\circ} \mathrm{C}$ : Phosphatase and tensin homolog (PTEN; 1:1,000; cat. no. 20399; Promab Biotechnologies, Inc.), beclin 1 (1:1,000; cat. no. 30182; Promab Biotechnologies), microtubule-associated protein 1 light chain 3B (LC3-II; 1:1,000; cat. no. 30363; Promab Biotechnologies), cyclin D1 (1:1,000; cat. no. WL01435a; Wanleibio, Co., Ltd.), caspase-3 (1:1,000; cat. no. WL04004; Wanleibio, Co., Ltd.), GAPDH (1:1,000; cat. no. 20035; Promab Biotechnologies), E-cadherin (1:1,000; cat. no. WL01482; Wanleibio, Co., Ltd.), Matrix metalloprotein-9, (MMP-9; 1:1,000; cat. no. WL03096; Wanleibio, Co., Ltd.) and vimentin (1:1,000; cat. no. WL01960; Wanleibio, Co., Ltd.). Samples were then incubated with horseradish peroxidase-conjugated secondary antibodies goat anti-mouse immunoglobulin IgG (1:2,000; cat. no. ab6789; Abcam) at room temperature for $2 \mathrm{~h}$. The enhanced chemiluminescence detection reagent (Thermo Fisher Scientific, Inc.) was used to visualize protein expression. Chemiluminescence was analyzed using ChemiDoc XRS system with Image Lab Software version 6.0 (Bio-Rad Laboratories, Inc.). GAPDH was used as an internal control.

MTT assay. T24 cells were cultured in 96-well plates at a volume of $100 \mu \mathrm{l}$ per well. After $48 \mathrm{~h}$ incubation at $37^{\circ} \mathrm{C}, 50 \mu \mathrm{l}$ MTT reagent (Sigma-Aldrich; Merck $\mathrm{KGaA}$ ) was added, and cells were cultured at $37^{\circ} \mathrm{C}$ for $4 \mathrm{~h}$. After removing the supernatant, $150 \mu \mathrm{l}$ of DMSO was added to detect absorbance at a wavelength of $570 \mathrm{~nm}$.

Wound healing assay. Cells were seeded into 6-well plates at a concentration of $5 \times 10^{5} / \mathrm{ml}$ and incubated at $37^{\circ} \mathrm{C}$ for $24 \mathrm{~h}$. After scratching an initial wound with a $10 \mu$ pipette tip in the cell monolayer, the distances of the wound area covered by cells was measured under an inverted microscope (CKX53; Olympus Corporation; magnification, x200) at 0, 24, and $48 \mathrm{~h}$ to detect migration.

Invasion assay. A total of $5 \times 10^{4}$ transfected cells suspended in $200 \mu \mathrm{l}$ serum-free DMEM were added to the upper chamber of a BioCoat ${ }^{\mathrm{TM}}$ Matrigel Invasion Chamber (Corning, Inc.). The lower chamber was filled with $1 \mathrm{ml}$ of DMEM supplied with $20 \% \mathrm{FBS}$. After culture with $5 \% \mathrm{CO}_{2}$ at $37^{\circ} \mathrm{C}$ for $24 \mathrm{~h}$, transwell chambers were inverted and stained with haematoxylin at $37^{\circ} \mathrm{C}$ for $10 \mathrm{~min}$. Excess stain was removed using PBS. The number of invading cells was determined according to five random fields of view under a light microscope (magnification, x300).

Flow cytometry. Annexin V/PI staining was conducted using the Annexin V-FITC Apoptosis Detection kit (BD Pharmingen; BD Biosciences) according to the manufacturer's protocol. Stained cells were analyzed with a flow cytometer using BD FACStation ${ }^{\mathrm{TM}} 6.1$ software (FACSCalibur; Becton, Dikinson and Company) within $1 \mathrm{~h}$.

Cell cycle analysis was conducted using a Cell Cycle Analysis kit (Beyotime Institute of Biotechnology) according to the manufactures' protocol. Cells were fixed with $5 \mathrm{ml} 70 \%$ ethanol at $4^{\circ} \mathrm{C}$ overnight, centrifuged at $1,208 \times \mathrm{g}$ at $4{ }^{\circ} \mathrm{C}$ for $5 \mathrm{~min}$ and washed with PBS. Subsequently, $50 \mu \mathrm{l}$ propidium iodide was added. Cells were resuspended and incubated in the dark at room temperature for $30 \mathrm{~min}$. The cell cycle was determined via flow cytometry (FACSCalibur; Becton, Dikinson and Company).

Statistical analysis. Statistical analysis was performed using SPSS 13.0 statistical software (SPSS, Inc.). Data are presented as the mean \pm standard deviation from at least three independent experiments. One-way ANOVA followed by Tukey's post hoc test was used to determine significance. $\mathrm{P}<0.05$ was considered to indicate a statistically significant difference. 
A
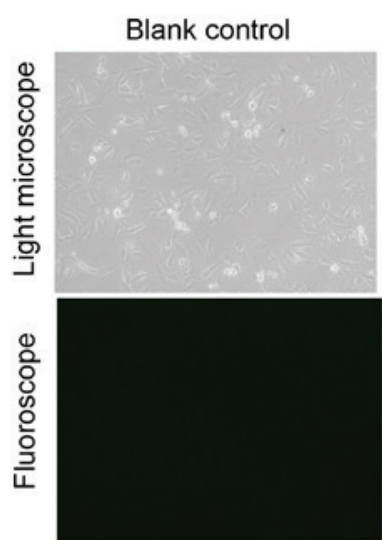

B
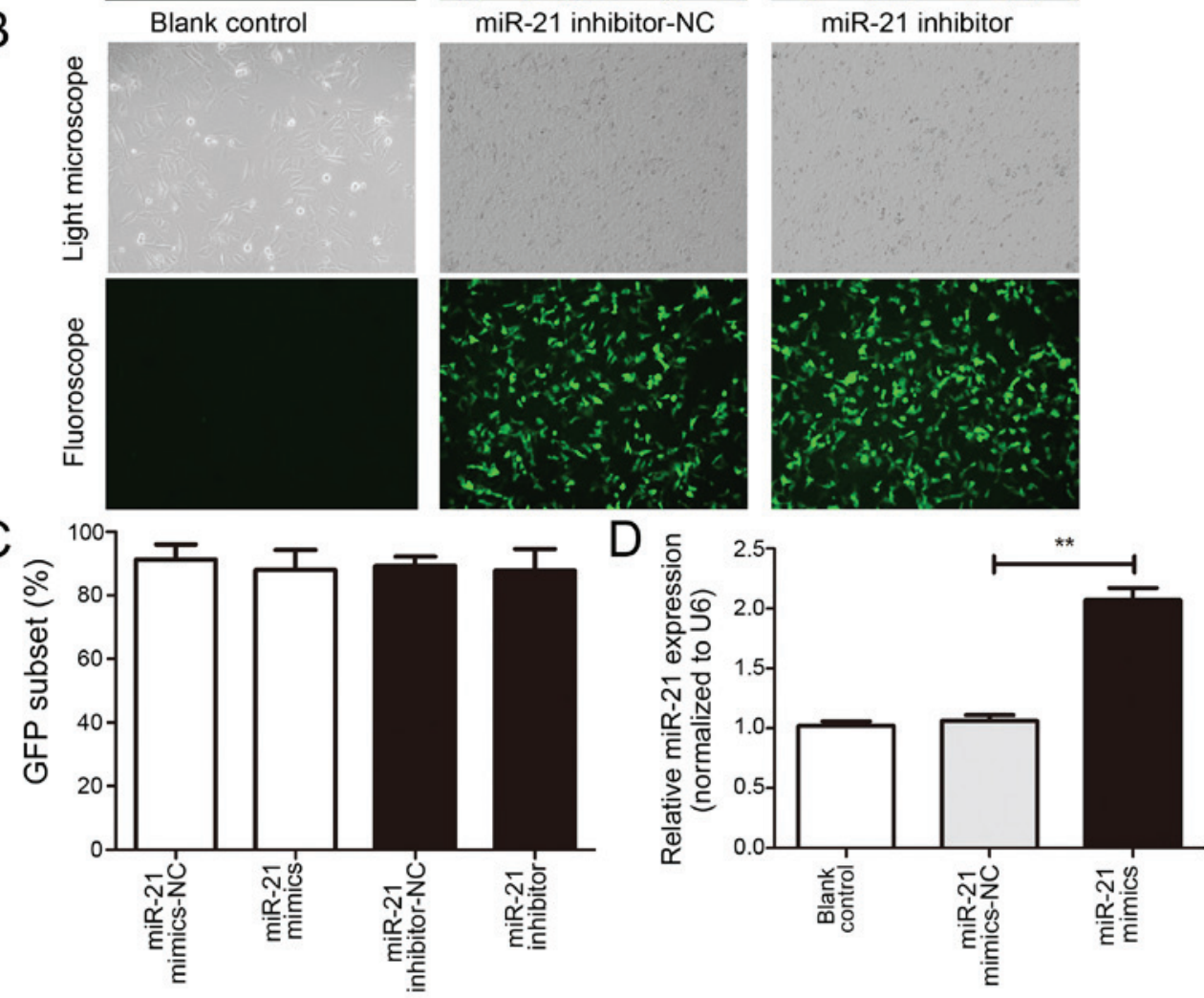

E

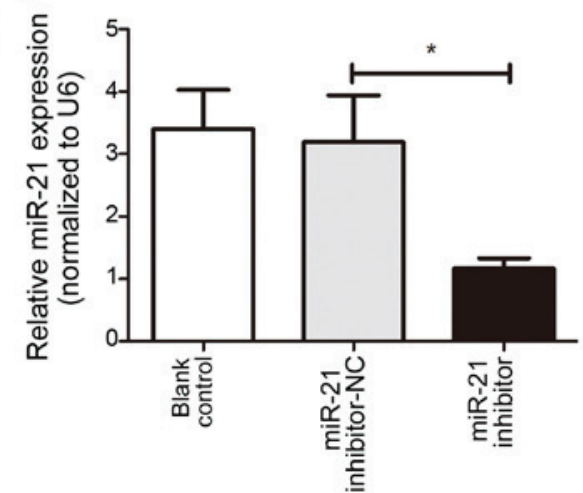

Figure 1. Transfection of T24 cells and the detection of miR-21 expression. Cells in the NC group, (A) mimic group and (B) inhibitor group (magnification, $\mathrm{x} 200$ ) were observed under light and fluorescence microscope. Transfection efficiency was indicated by distribution of (C) green fluorescent cells, which was $>80 \%$. miR-21 expression was detected in the (D) mimic and (E) inhibitor treated groups. ${ }^{* *} \mathrm{P}<0.01$ vs. NC groupgroup (C). ${ }^{*} \mathrm{P}<0.05$ vs. NC groupgroup (D). miR, microRNA; NC, negative control; miR, microRNA.

\section{Results}

Stably transfected T24 groups were established. To investigate the effects of miR- 21 on bladder cancer T24 cells, miR-21 mimics and inhibitors were obtained and transfected into T24 cells. Transfection efficiency was determined by analyzing the percentage of fluorescent cells (Fig. 1A and B). The percentage of fluorescence was $>80 \%$ in the NC, mimic and inhibitor groups. 

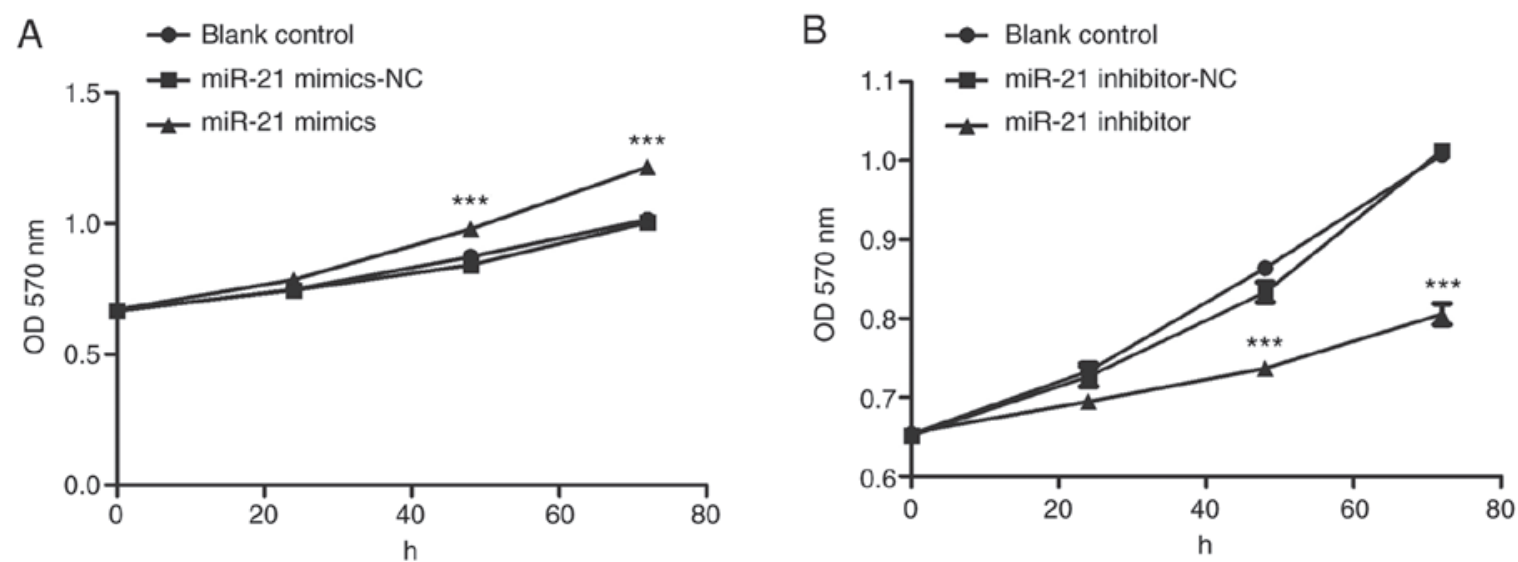

Figure 2. Relative cell proliferation as measured using an MTT assay. The number of proliferative cells in the (A) mimic and (B) inhibitor groups were measured via MTT. ${ }^{* * *} \mathrm{P}<0.001$ vs. control and NC groups. NC, negative control; OD, optical density; miR, microRNA.

A
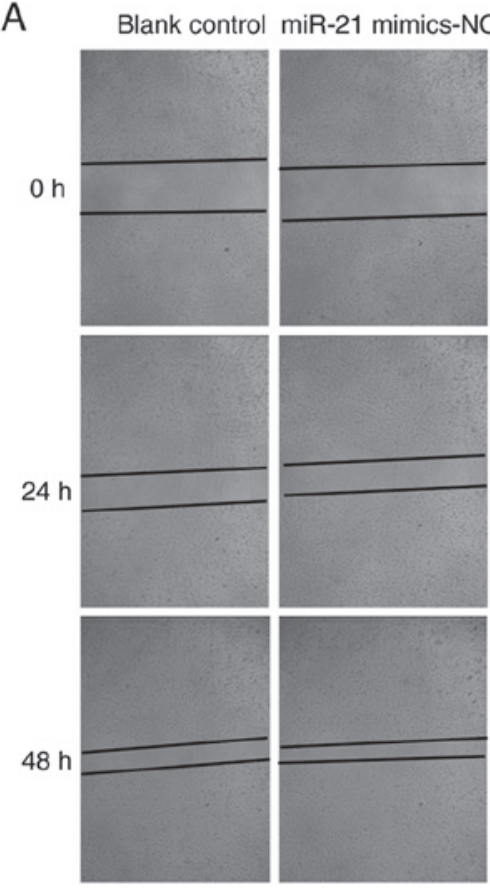

C
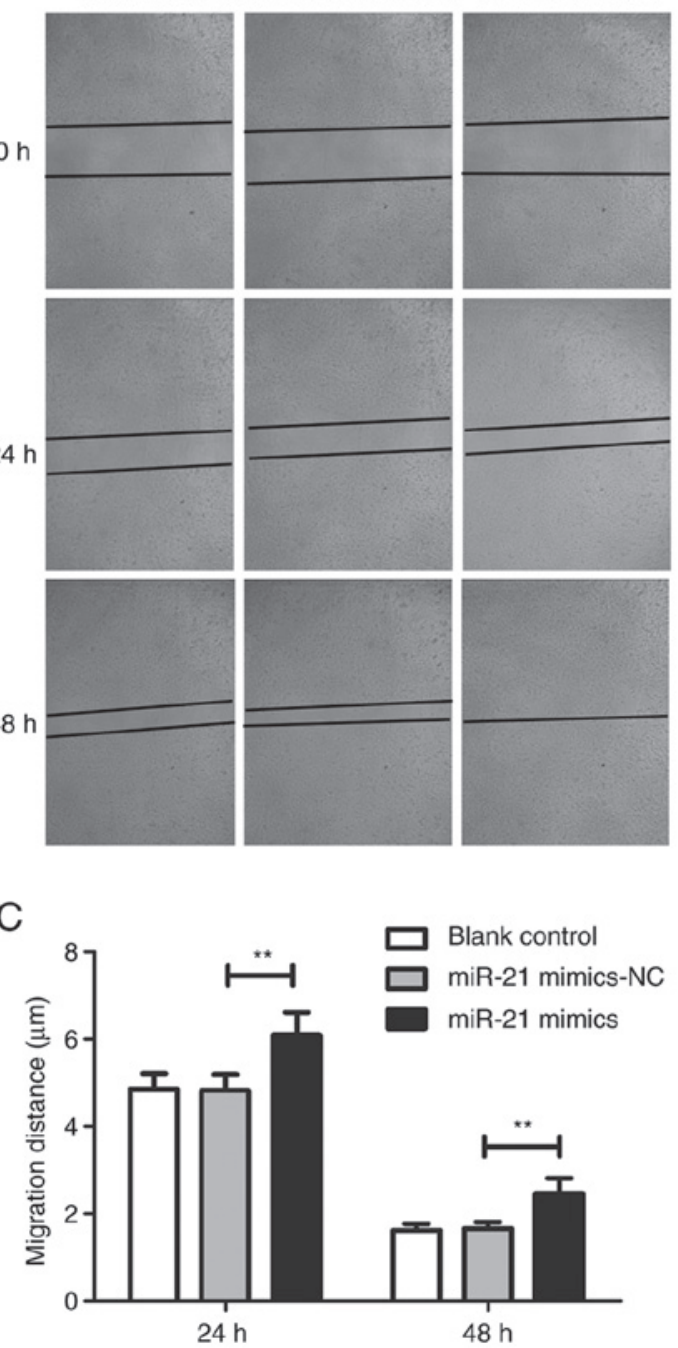

B

$48 \mathrm{~h}$
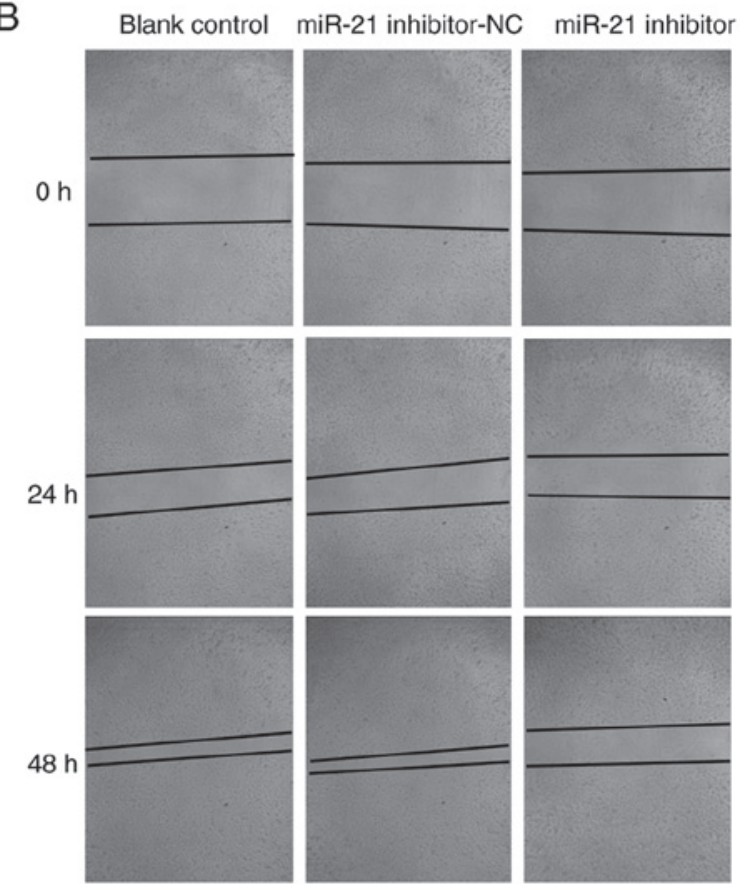

D

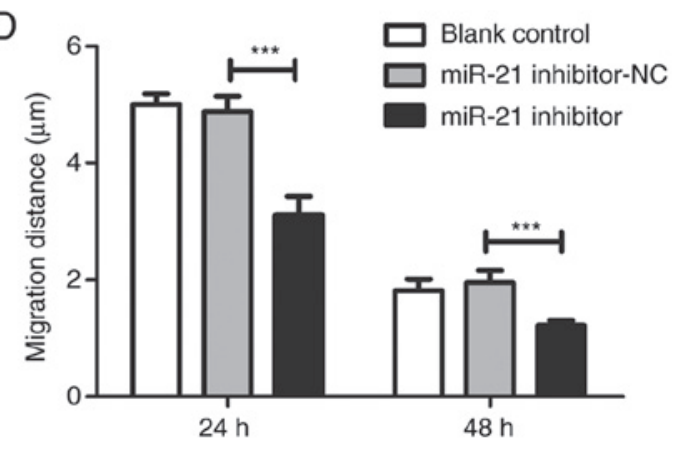

Figure 3. T24 cell migration as measured using a wound healing assay. Cell migration was determined in the (A) mimic group and (B) inhibitor group following transfection for 24 and $48 \mathrm{~h}$ (magnification, x200). Migration distances of the (C) mimic group and (D) inhibitor group were subsequently calculated. ${ }^{* * *} \mathrm{P}<0.01$ and ${ }^{* * *} \mathrm{P}<0.001$ vs. NC groups. NC, negative control; miR, microRNA.

Effect of miR-21 mimic and miR-21 inhibitor on the expression of $m i R-21$. The results of RT-qPCR demonstrated a significant increase in miR-21 expression in the mimic group and a significant inhibition in the inhibitor group when compared with the NC group (Fig. 1C and D). No significant differences were revealed between the $\mathrm{NC}$ and Con groups. 
A

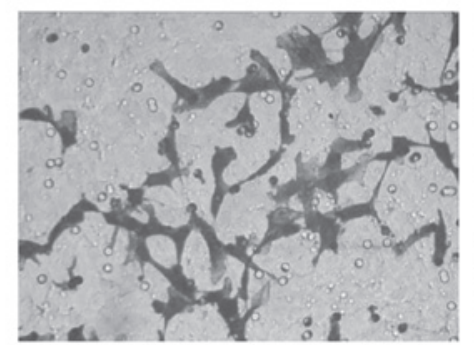

B

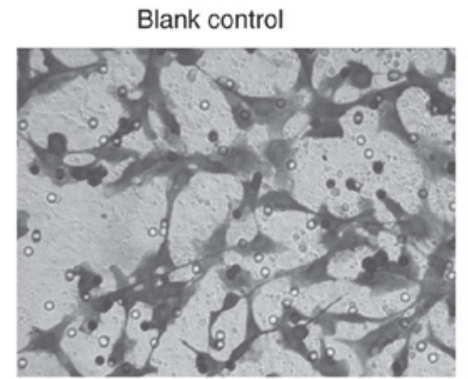

miR-21 mimics-NC

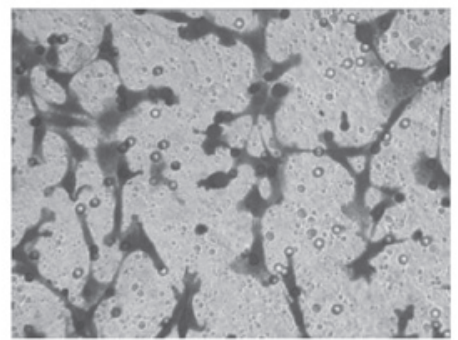

miR-21 inhibitor-NC

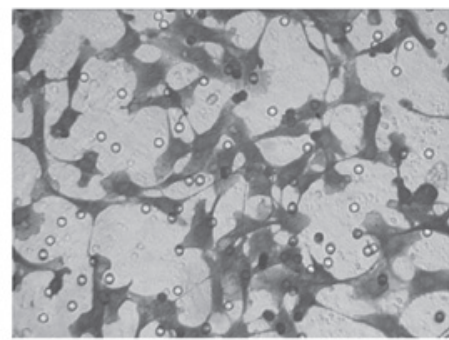

miR-21 mimics

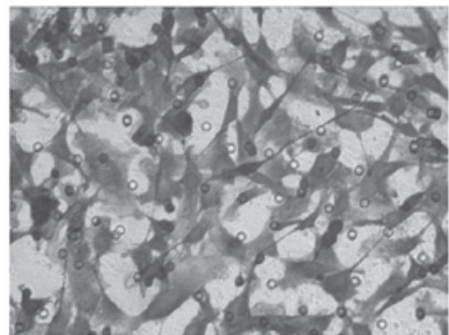

miR-21 inhibitor

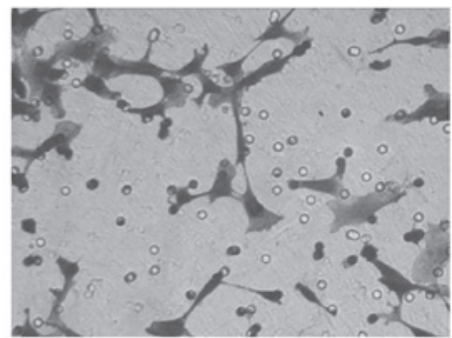

C
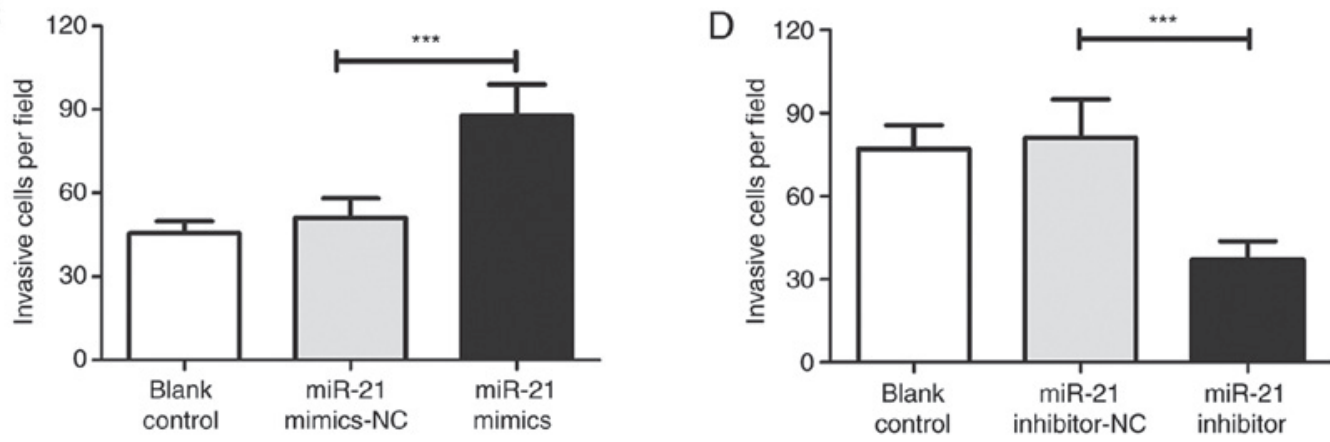

Figure 4. T24 cells invasion as measured using a transwell assay. The number of invasive cells in the (A) mimic and (B) inhibitor group was determined following a transwell assay (magnification, $x 300$ ). The number of invasive cells per field was subsequently calculated in the (C) mimic and (D) inhibitor group. ${ }^{* * *} \mathrm{P}<0.001$ vs. NC groups. NC, negative control; miR, microRNA.
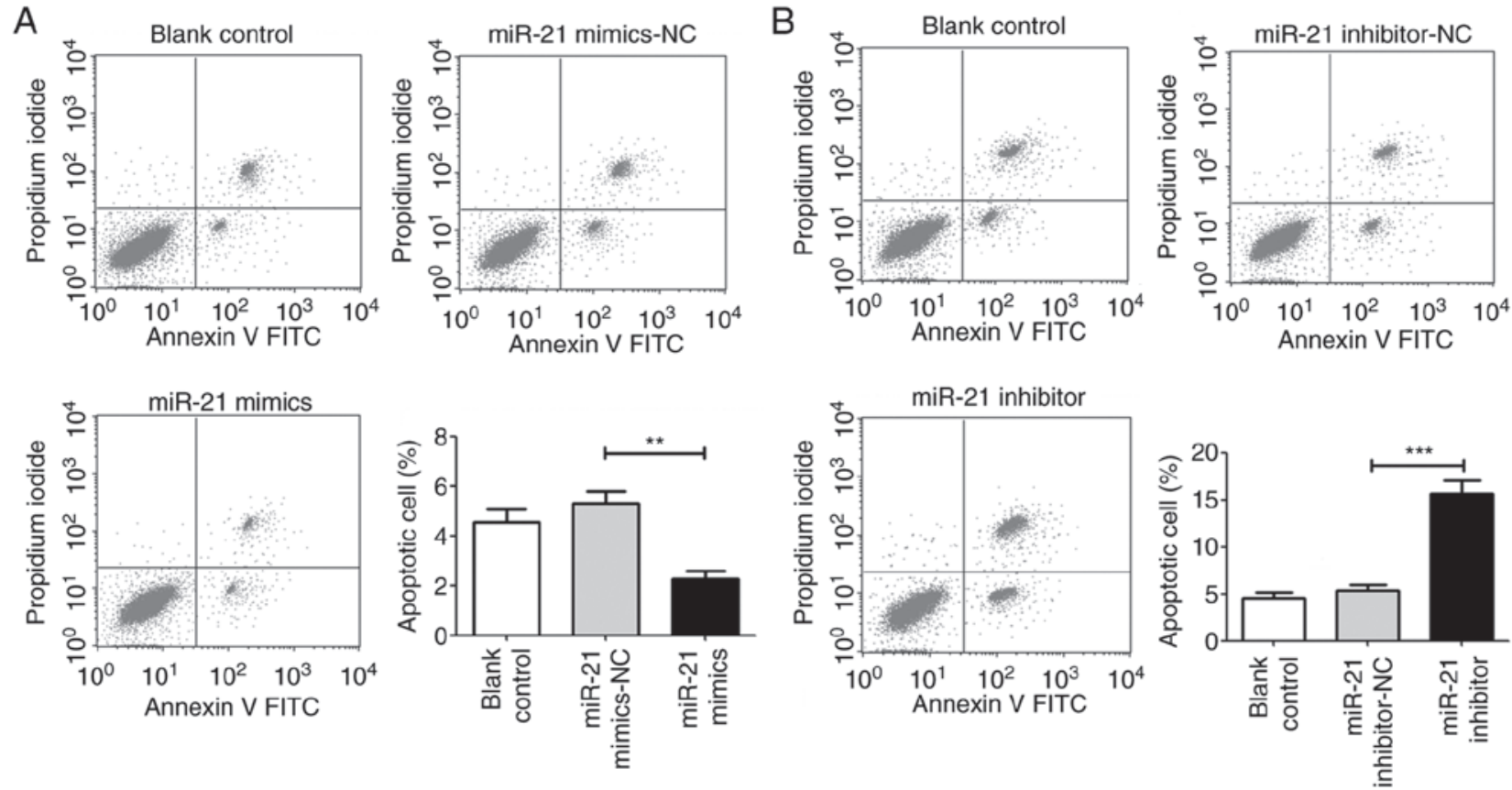

Figure 5. T24 cell apoptosis as detected using flow cytometry. The number of apoptosis cells in the (A) mimic and (B) inhibitor group was detected via flow cytometry. ${ }^{* *} \mathrm{P}<0.01$ and ${ }^{* * *} \mathrm{P}<0.001$ vs. NC groups. NC, negative control; miR, microRNA. 

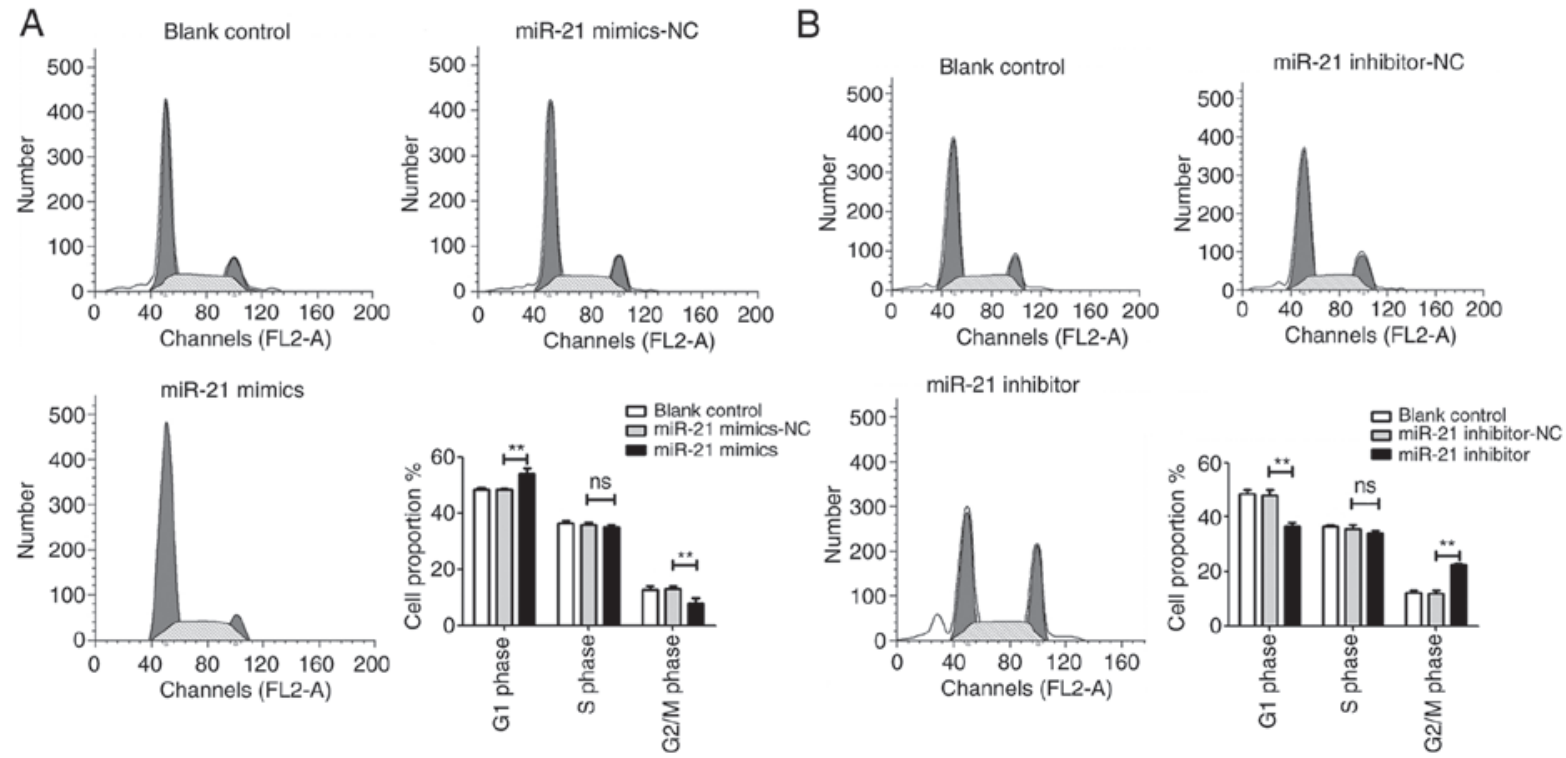

Figure 6. T24 cell cycle analysis was performed using flow cytometry. The cycle of T24 cells was analyzed and quantified in the (A) mimic and (B) inhibitor group. ${ }^{* *} \mathrm{P}<0.01$ vs. NC groups. ns vs. NC groups. NC, negative control; miR, microRNA; ns, No significance.

A

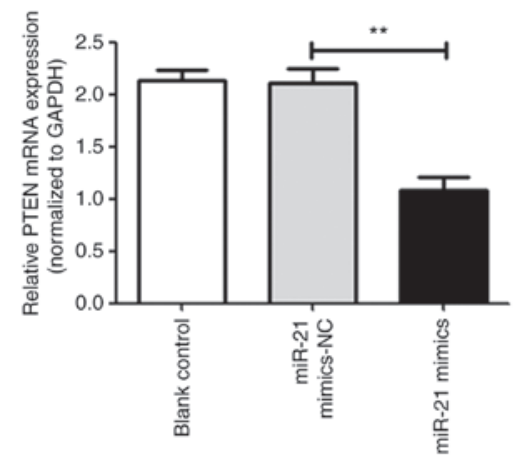

B

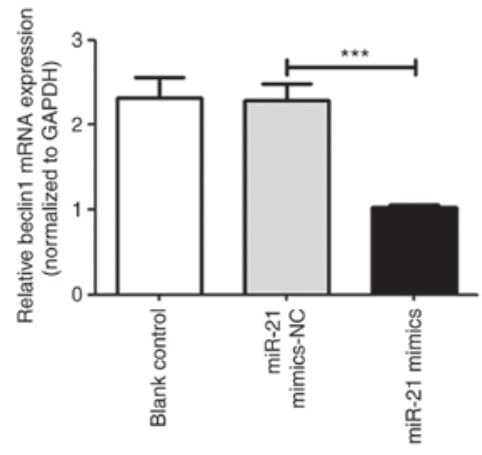

$\mathrm{C}$

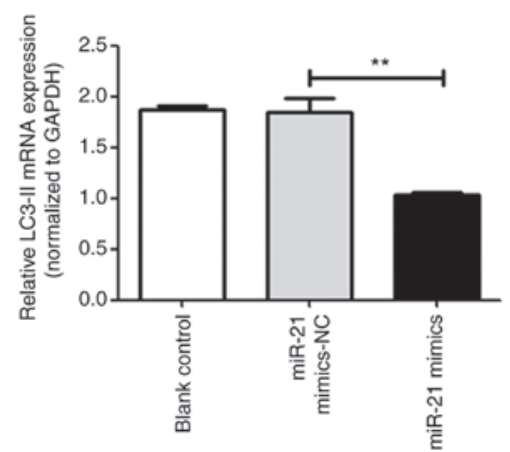

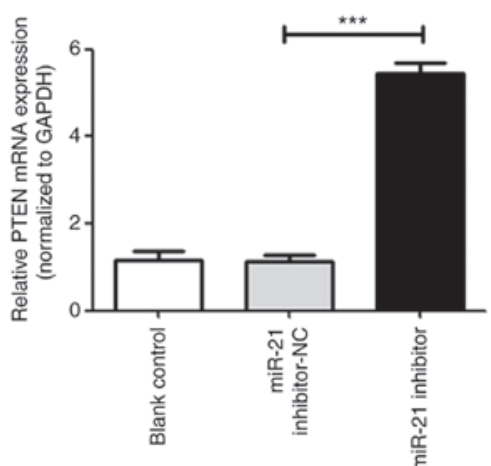
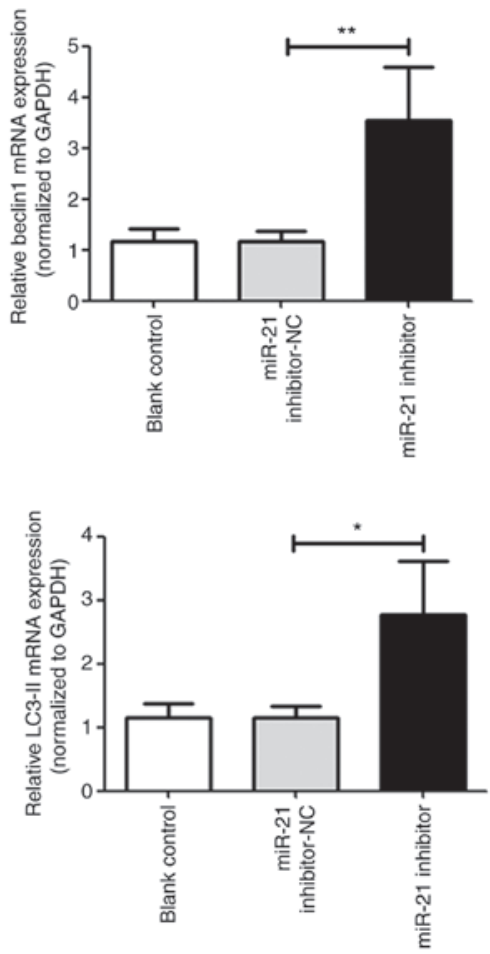

Figure 7. Analysis of various mRNAs associated with T24 cell proliferation, apoptosis and autophagy. The mRNA expression of (A) PTEN, (B) beclin-1, and (C) LC3-II in T24 cells was measured via reverse transcription-quantitative PCR. ${ }^{*} \mathrm{P}<0.05,{ }^{* *} \mathrm{P}<0.01$ and ${ }^{* * *} \mathrm{P}<0.001$ vs. NC groups. 

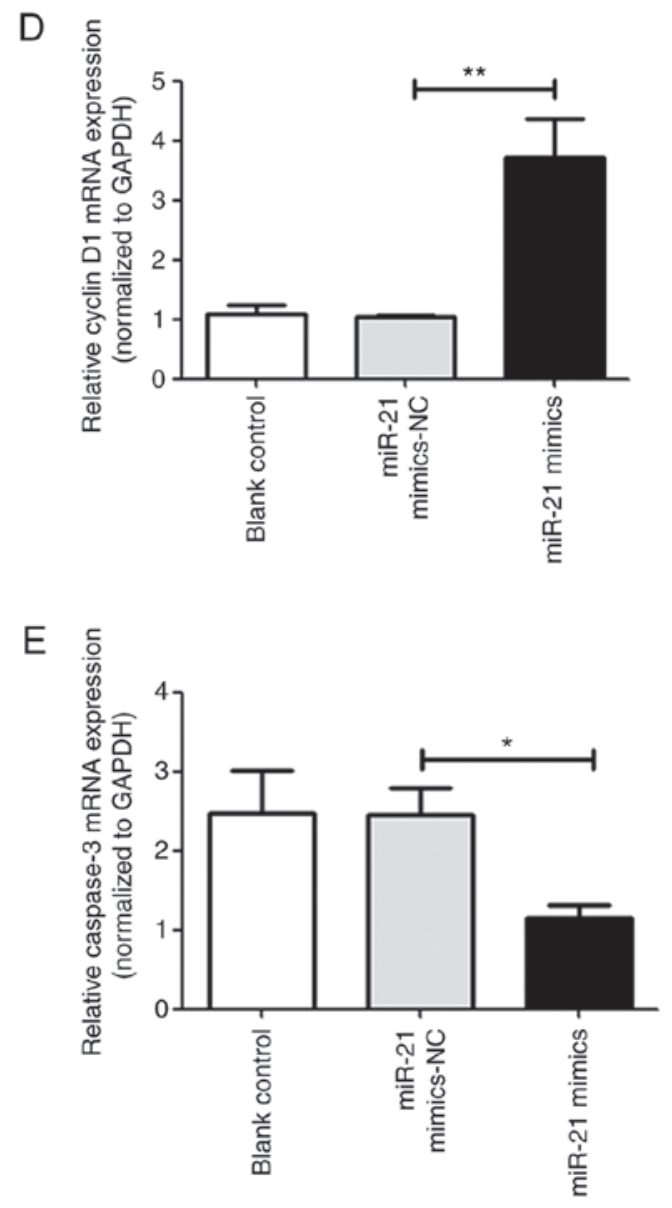
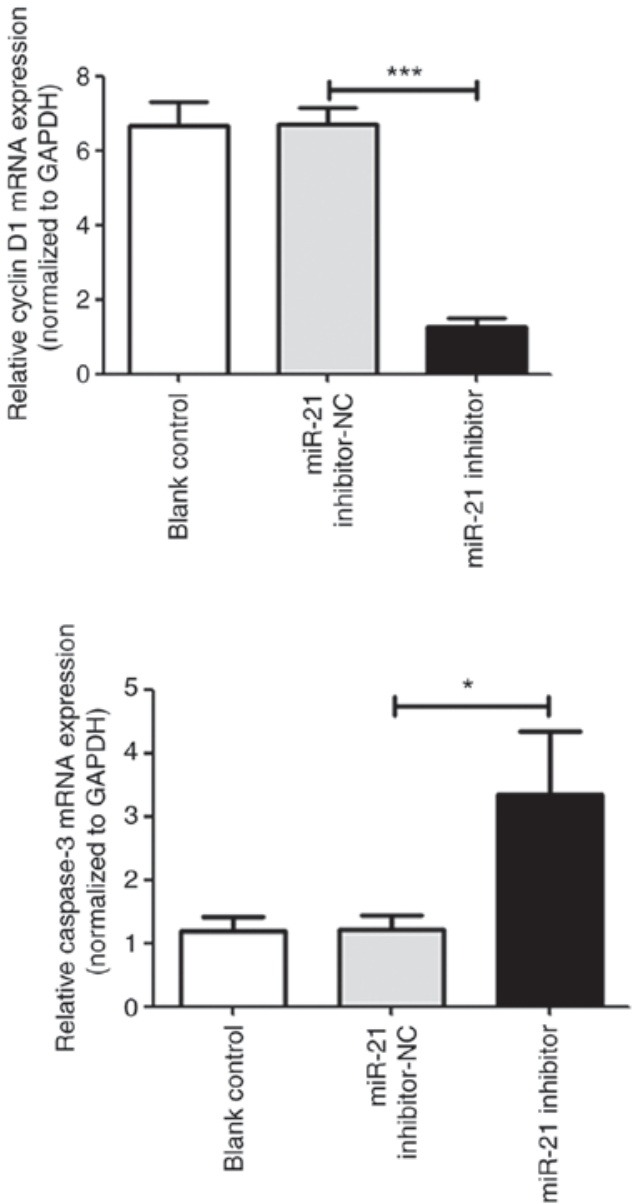

Figure 7. Continued. Analysis of various mRNAs associated with T24 cell proliferation, apoptosis and autophagy. The mRNA expression of (D) cyclin D1 and (E) caspase- 3 in T2 4 cells was measured via reverse transcription-quantitative PCR. ${ }^{*} \mathrm{P}<0.05,{ }^{* *} \mathrm{P}<0.01$ and ${ }^{* * * *} \mathrm{P}<0.001$ vs. NC groups. PTEN, phosphatase and tensin homolog; LC3-II, microtubule-associated protein 1 light chain 3B; NC, negative control; miR, microRNA.

miR-21 promotes the proliferation, migration and invasion of $T 24$ cells. The results of the MTT assay revealed that the proliferation of cells in the mimic group was significantly increased compared with the Con and NC groups in a time-dependent manner (Fig. 2A). In contrast, the proliferation of cells in the inhibitor group was significantly inhibited (Fig. 2B). Compared with the NC group, wound healing and invasion assays demonstrated that miR-21 mimic transfection increased the migration and invasiveness of T24 cells (Figs. 3 and 4). However, the migration and invasion of T24 cells were significantly inhibited in the inhibitor group.

miR-21 inhibits apoptosis and arrests the G1 phase of T24 cells. Flow cytometry was performed to evaluate the influence of miR-21 on cell apoptosis and cell cycle distribution. The results revealed that when compared with the NC group, cells transfected with the miR-21 mimic decreased cell apoptosis and arrested T24 cells at the G1 phase. However, the miR-21 inhibitor significantly induced cell apoptosis and decreased the proportion of cells in the G1 phase (Figs. 5 and 6).

Effect of miR-21 expression on the proteins associated with the proliferation, migration, invasion, epithelial mesenchymal transition and autophagy of T24 cells. To further elucidate the possible mechanism of miR-21mediated cell processes, RT-qPCR and western blotting were performed to detected the mRNA and protein expression of PTEN, beclin 1, LC3-II, cyclin D1, caspase-3, E-cadherin, matrix metallopeptidase 9 (MMP-9) and vimentin. In the miR-21 mimic group, compared with the NC group, the results revealed that the mRNA and protein expression of PTEN, beclin 1, LC3-II, caspase-3 and E-cadherin were significantly decreased. In addition, the mRNA and protein expression of cyclin D1, MMP-9 and vimentin were significantly increased (Figs. 7-10). However, increased mRNA and protein expression of PTEN, beclin 1, LC3-II, caspase-3 and E-cadherin and decreased mRNA and protein expression of cyclin D1, MMP-9 and vimentin were induced after treatment with the miR-21 inhibitor.

\section{Discussion}

MiRNAs widely regulate gene expression and are associated with the malignant development and survival of various types of cancer $(15,16)$. A previous study reported that miR-21 was increased in $\mathrm{BC}$ tissue and was associated with high rates of recurrence (17). Although the oncogenic role of miR-21 in $\mathrm{BC}$ has been previously indicated, the functional mechanism 

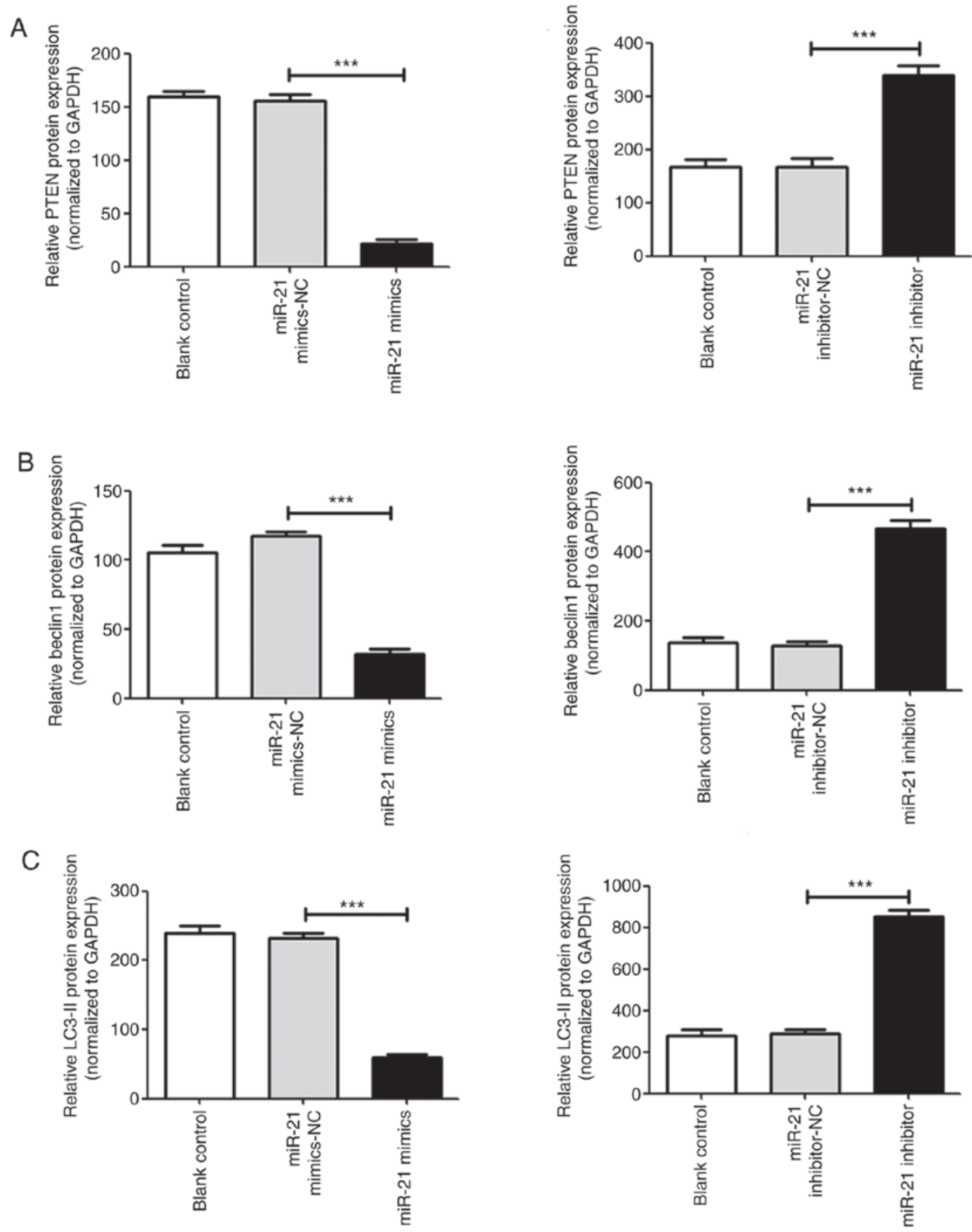

Figure 8. Analysis of various proteins associated with T24 cell proliferation, apoptosis and autophagy. The protein expression of (A) PTEN, (B) beclin-1, and (C) LC3-II protein expression in T24 cells was measured via western blotting. ${ }^{* * *} \mathrm{P}<0.001$ vs. NC groups.

of miR-21 has not yet been fully elucidated and therefore deserves further study.

The present study demonstrated that upregulated miR-21 significantly increased the proliferation, migration and invasion of T24 cells, and arrested the cell cycle at the G1 phase. This is congruent with results obtained with other cancer cell lines $(7,8)$. To investigate the underlying mechanism of miR-21, the expression of PTEN, beclin 1, LC3-II, cyclin D1, caspase-3, E-cadherin, MMP-9 and vimentin were examined. The results revealed that the expression of PTEN, beclin 1, LC3-II, caspase-3 and E-cadherin was decreased, while the expression of cyclin D1, MMP-9 and vimentin was increased in the mimic group.
Autophagy is a complex intracellular process that modulates several cellular functions (14). Abnormal levels of autophagy have been continuously associated with human inflammatory disorders and cancer $(18,19)$. Although autophagy may suppress tumors in certain cases, it may also serve an oncogenic role in cancer via microenvironmental stress responses and metabolism control (20-22). Thus, autophagy has a dual effect.

Various signaling pathways, including the PTEN/ AKT/mTOR pathway, are associated with autophagy regulation $(23,24)$. The current study revealed that autophagy-associated proteins, beclin 1 and LC3-II, were upregulated following miR-21 mimic transfection, while 

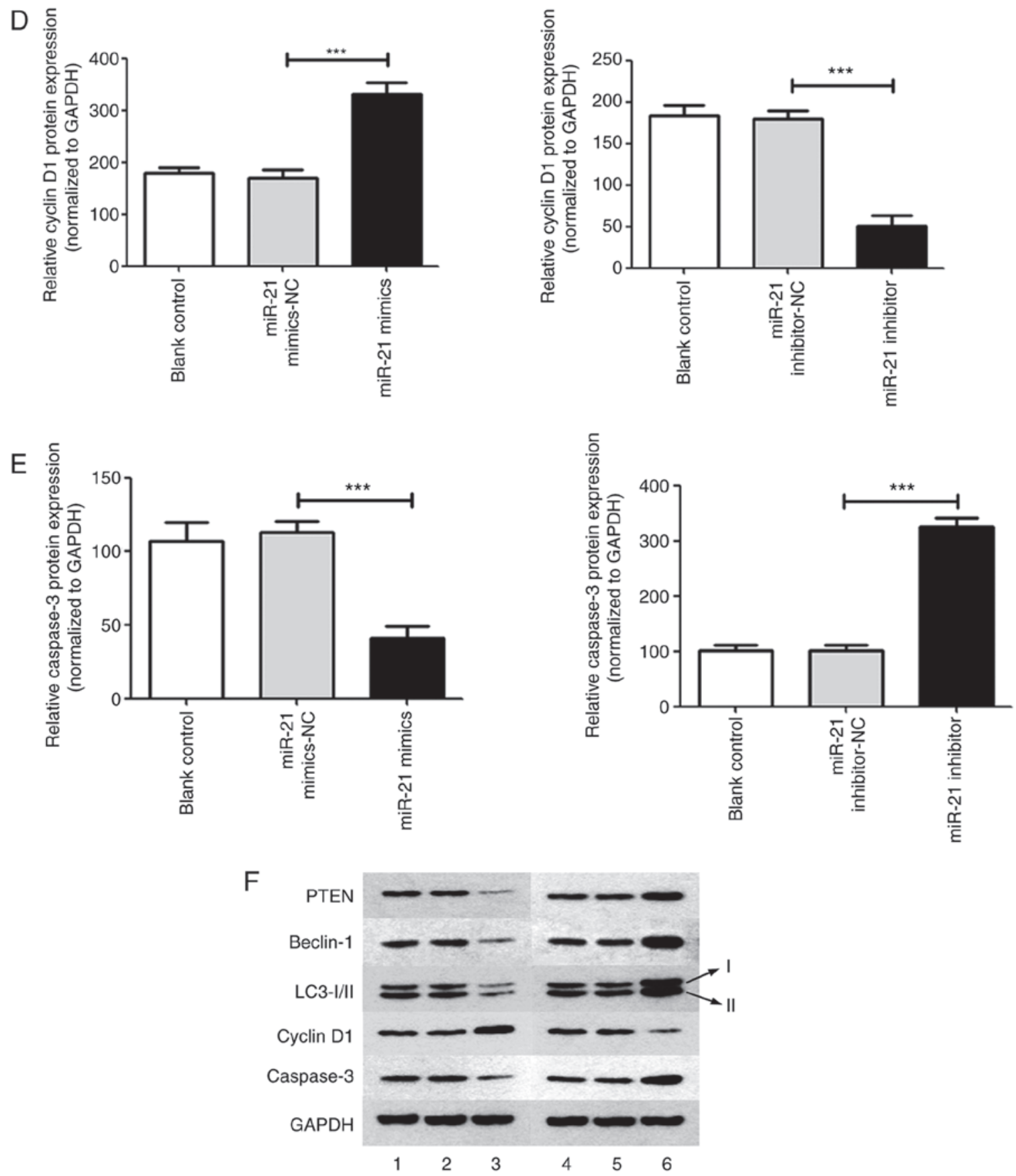

Figure 8. Continued. Analysis of various proteins associated with T24 cell proliferation, apoptosis and autophagy. The protein expression of (D) cyclin D1 and (E) caspase-3 protein expression in T24 cells was measured via (F) western blotting. ${ }^{* * * *} \mathrm{P}<0.001$ vs. NC groups. PTEN, phosphatase and tensin homolog; LC3-II, microtubule-associated protein 1 light chain 3B; 1, blank control; 2, miR-21 mimic-NC; 3, miR-21 mimic; 4, blank control; 5, miR-21 inhibitor-NC; 6, miR-21 inhibitor; NC, negative control; miR, microRNA.

PTEN was downregulated. To some extent, this result may indicate that miR-21 inhibits autophagy in T24 cells via a PTEN-mediated pathway, resulting in changes to the viability and proliferation of $\mathrm{T} 24$ cells.

The results of MTT assay and flow cytometric analysis revealed that the miR-21 mimic promoted cell proliferation in a time-dependent manner, which was associated with suppressed apoptosis. To address this mechanism, the expression of cyclin D1 and caspase-3 were detected. Cyclin D1 is a major regulator of cell cycle progression that is overexpressed in carcinomas (25). Increased cyclin D1 expression can accelerate cell cycle progression and DNA synthesis (26). The present study determined that cyclin D1 expression was increased following transfection with miR-21 mimics. It was further demonstrated that upregulation of miR-21 promoted G0/G1 phase cell cycle arrest by affecting cyclin D1 levels. Apoptosis deregulation serves an important role in cancer development (27). Caspases are key mediators of this process (28). In the current study, the expression of caspase-3 was significantly increased following miR-21 mimic transfection. The results also demonstrated that the G0/G1 cell cycle arrest and apoptosis induced by miR-21 may provide favorable conditions for the development of BC cells. 

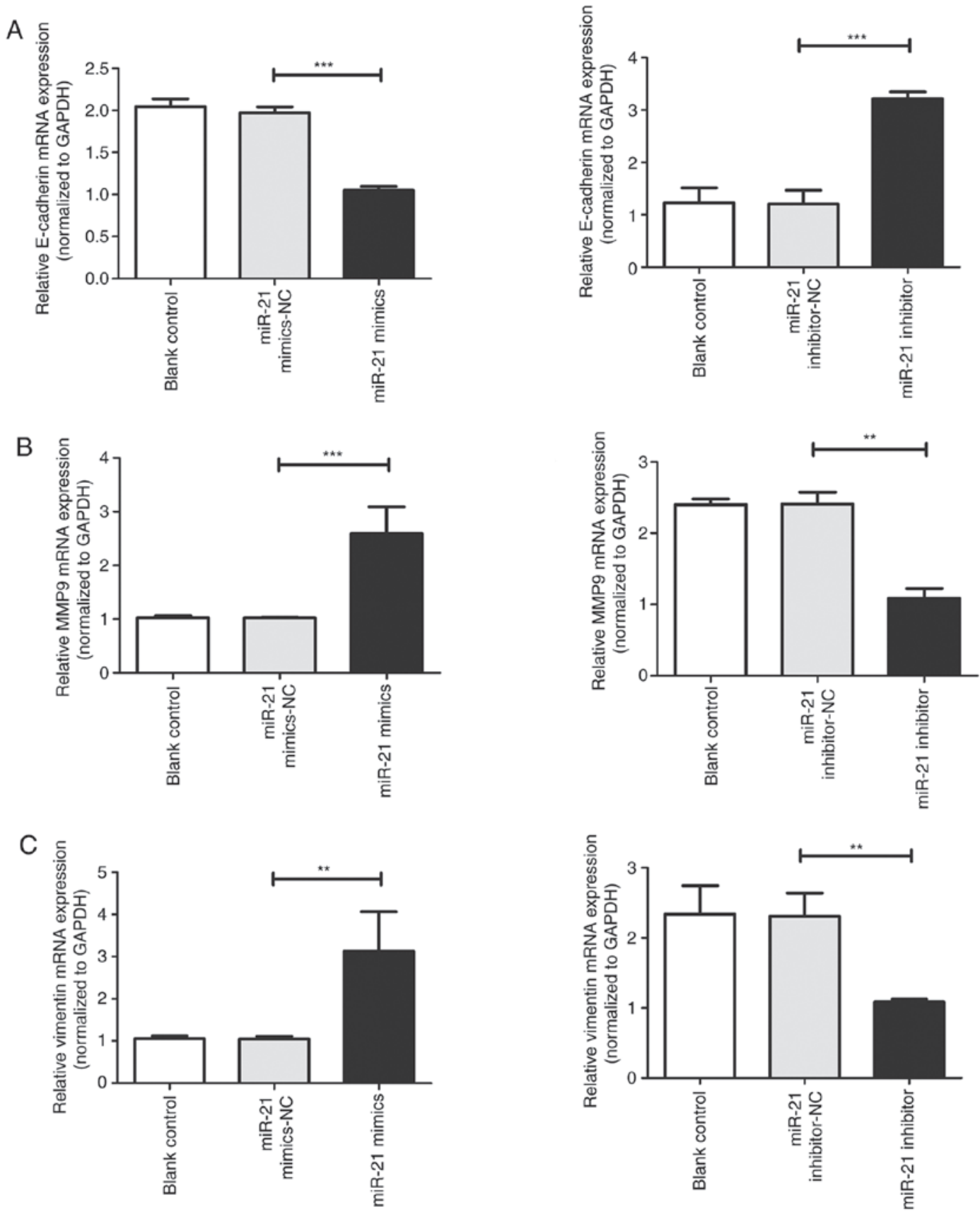

Figure 9. Analysis of various mRNAs associated with T24 cell invasion and epithelial to mesenchymal transition. The mRNA expression of (A) E-cadherin, (B) MMP-9 and (C) vimentin mRNA was measured by reverse transcription-quantitative PCR. ${ }^{* * *} \mathrm{P}<0.01$ and ${ }^{* * *} \mathrm{P}<0.001$ vs. NC groups. MMP-9, matrix metallopeptidase 9; NC, negative control; miR, microRNA.

Metastasis is an important characteristic of cancer. MMP is a family of neutral proteinases that allow cancer cells to migrate and invade (29). The current data revealed a significant increase in MMP-9 and the increased invasion of cells in the miR-21 mimic group. These results confirmed that miR-21 served a promoting role in the invasiveness of T24 cells.

Epithelial to mesenchymal transition (EMT) may provide favorable conditions for increasing cell mobility $(30,31)$. EMT is characterized by the suppression of epithelial-associated genes, the upregulation of mesenchymal-associated genes, and the deregulation of various transcription factors $(32,33)$. The results of the current study demonstrated that miR-21 increased the migration and invasion of T24 cells. As previously described, EMT is closely associated with cell invasion. Subsequently, the results of western blotting revealed that miR-21 decreased the expression of E-cadherin and increased the expression of vimentin. It was therefore hypothesized that miR-21 may decrease cell migration and invasion by inhibiting EMT.

A previous study reported that autophagy could inhibit EMT and metastasis in glioblastoma cells (34). However, autophagy also inhibits the migration and invasion of cancer cells by suppressing certain transcription factors such as SNAIL and SLUG (35). In the present study, autophagy was suppressed while EMT was promoted by miR-21. Whether 

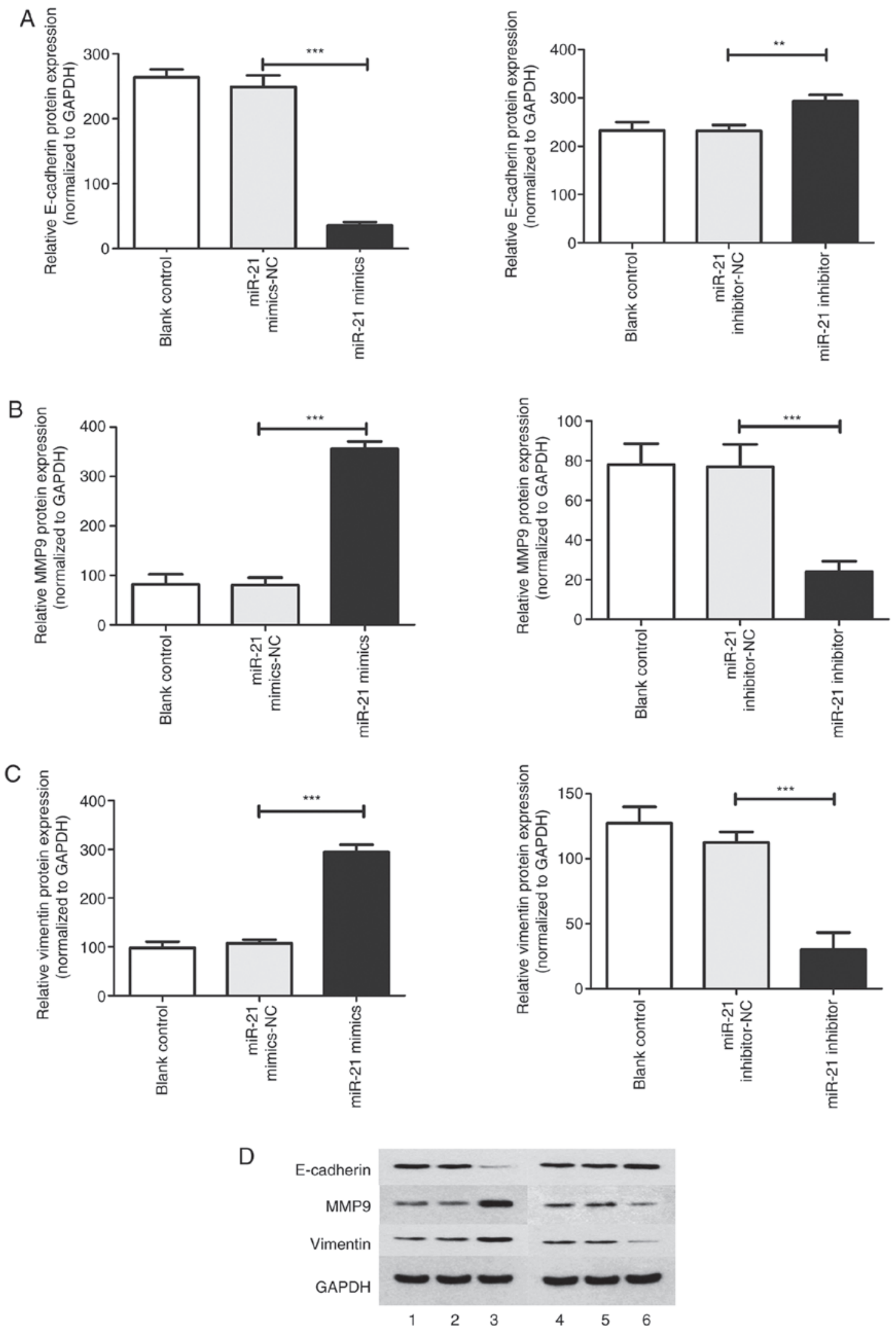

Figure 10. Analysis of various proteins associated with T24 cell invasion and epithelial to mesenchymal transition. The protein expression of (A) E-cadherin, (B) MMP-9 and (C) vimentin in T24 cells was measured via (D) western blotting. ${ }^{* *} \mathrm{P}<0.01$ and ${ }^{* * *} \mathrm{P}<0.001$ vs. NC groups. 1 , blank control; 2 , miR-21 mimic-NC; 3, miR-21 mimic; 4, blank control; 5, miR-21 inhibitor-NC; 6, miR-21 inhibitor; NC, negative control; miR, microRNA.

there is a link between the autophagy-mediated regulation of EMT and bladder tumourigenesis is unclear and as such requires further study.
Collectively, the present data suggested that miR-21 inhibited autophagy and promoted the malignant development of the $\mathrm{BC}$ cell line, $\mathrm{T} 24$, in vitro. These results indicated that miR-21 
may serve as a potential target to inhibit the development of $\mathrm{BC}$. To the best of our knowledge, the current study is the first comprehensively assess the role of miR-21 in the cancer development of the BC T24 cell line, as well as its functional mechanism. However, the lack of in vivo experiments is the main limitation of the present study. Furthermore, the use of only one cell line may also limit results. Further studies are therefore required to verify these effects and to clarify the mechanism by which miR-21 is involved in the development of $\mathrm{BC}$.

\section{Acknowledgements}

Not applicable.

\section{Funding}

The current study was supported by the National Natural Science Foundation of China (grant no. 81602241) and the Scientific Project of Health Commission of Hunan Province (grant no. B2019127).

\section{Availability of data and materials}

The datasets used and/or analyzed are available from the corresponding author on reasonable request.

\section{Authors' contributions}

$\mathrm{ZH}$ designed the experiments and drafted the manuscript. HZ and ZS performed the experiments and collected the data. FK and CY analyzed and interpreted data. All authors read and approved the manuscript.

\section{Ethics approval and consent to participate}

The present study was approved by the Ethics Committee of The First Affiliated Hospital of University of South China.

\section{Patient consent for publication}

Not applicable.

\section{Competing interests}

The authors declare that they have no competing interests

\section{References}

1. Fankhauser CD and Mostafid H: Prevention of bladder cancer incidence and recurrence: Nutrition and lifestyle. Curr Opin Urol 28: 88-92, 2018.

2. Antoni S, Ferlay J, Soerjomataram I, Znaor A, Jemal A and Bray F: Bladder cancer incidence and mortality: A global overview and recent trends. Eur Urol 71: 96-108, 2017.

3. Liu Z, Xie D and Zhang H: Long noncoding RNA neuroblastoma-associated transcript 1 gene inhibits malignant cellular phenotypes of bladder cancer through miR-21/SOCS6 axis. Cell Death Dis 9: 1042, 2018.

4. Heishima K, Meuten T, Yoshida K, Mori T and Thamm DH: Prognostic significance of circulating microRNA-214 and-126 in dogs with appendicular osteosarcoma receiving amputation and chemotherapy. BMC Vet Res 15: 39, 2019.
5. Xue Y, Ge Y, Kang M, Wu C, Wang Y, Rong L and Fang Y: Selection of three miRNA signatures with prognostic value in non-M3 acute myeloid leukemia. BMC Cancer 19: 109, 2019.

6. Ribas J, Ni X, Castanares M, Liu MM, Esopi D, Yegnasubramanian S, Rodriguez R, Mendell JT and Lupold SE: A novel source for miR-21 expression through the alternative polyadenylation of VMP1 gene transcripts. Nucleic Acids Res 40: 6821-6833, 2012.

7. Ni K, Wang D, Xu H, Mei F, Wu C, Liu Z and Zhou B: miR-21 promotes non-small cell lung cancer cells growth by regulating fatty acid metabolism. Cancer Cell Int 19: 219, 2019.

8. Chai C, Song LJ, Han SY, Li XQ and Li M: MicroRNA-21 promotes glioma cell proliferation and inhibits senescence and apoptosis by targeting SPRY1 via the PTEN/PI3K/AKT signaling pathway. CNS Neurosci Ther 24: 369-380, 2018.

9. Folini M, Gandellini P, Longoni N, Profumo V, Callari M, Pennati M, Colecchia M, Supino R, Veneroni S, Salvioni R, et al: miR-21: An oncomir on strike in prostate cancer. Mol Cancer 9: 12, 2010.

10. Qiu YF, Wang MX, Meng LN, Zhang R and Wang W: MiR-21 regulates proliferation and apoptosis of oral cancer cells through TNF- $\alpha$. Eur Rev Med Pharmacol Sci 22: 7735-7741, 2018.

11. Badr M, Said H, Louka ML, Elghazaly HA, Gaballah A and Atef Abd El Mageed M: MicroRNA-21 as a predictor and prognostic factor for trastuzumab therapy in human epidermal growth factor receptor 2-positive metastatic breast cancer. J Cell Biochem 120: 3459-3466, 2019.

12. Hao JP and Ma A: The ratio of miR-21/miR-24 as a promising diagnostic and poor prognosis biomarker in colorectal cancer. Eur Rev Med Pharmacol Sci 22: 8649-8656, 2018.

13. Zhang HH, Qi F, Cao YH, Zu XB and Chen MF: Expression and clinical significance of microRNA-21, maspin and vascular endothelial growth factor- $\mathrm{C}$ in bladder cancer. Oncol Lett 10: 2610-2616, 2015.

14. Livak KJ and Schmittgen TD: Analysis of relative gene expression data using real-time quantitative PCR and the 2(-Delta Delta C(T)) method. Methods 25: 402-408, 2001.

15. He Y, Liu H, Jiang L, Rui B, Mei J and Xiao H: miR-26 induces apoptosis and inhibits autophagy in non-small cell lung cancer cells by suppressing TGF- $\beta 1$-JNK signaling pathway. Front Pharmacol 9: 1509, 2019.

16. Iswariya GT, Paital B, Padma PR and Nirmaladevi R: microRNAs: Epigenetic players in cancer and aging. Front Biosci (Schol Ed) 11: 29-55, 2019.

17. Kroemer G, Mariño G and Levine B: Autophagy and the integrated stress response. Mol Cell 40: 280-293, 2010.

18. Menzies FM, Fleming A, Caricasole A, Bento CF, Andrews SP, Ashkenazi A, Füllgrabe J, Jackson A, Jimenez Sanchez M, Karabiyik C, et al: Autophagy and neurodegeneration: Pathogenic mechanisms and therapeutic opportunities. Neuron 93: 1015-1034, 2017.

19. Monkkonen T and Debnath J: Inflammatory signaling cascades and autophagy in cancer. Autophagy 14: 190-198, 2018.

20. Kung CP, Budina A, Balaburski G, Bergenstock MK and Murphy M: Autophagy in tumor suppression and cancer therapy. Crit Rev Eukaryot Gene Expr 21: 71-100, 2011.

21. White E: The role for autophagy in cancer. J Clin Invest 125 : 42-46, 2015.

22. Amaravadi R, Kimmelman AC and White E: Recent insights into the function of autophagy in cancer. Genes Dev 30: 1913-1930, 2016.

23. Jia L, Huang S, Yin X, Zan Y, Guo Y and Han L: Quercetin suppresses the mobility of breast cancer by suppressing glycolysis through Akt-mTOR pathway mediated autophagy induction. Life Sci 208: 123-130, 2018.

24. Zhao GS, Gao ZR, Zhang Q, Tang XF, Lv YF, Zhang ZS, Zhang Y, Tan QL, Peng DB, Jiang DM and Guo QN: TSSC3 promotes autophagy via inactivating the Src-mediated PI3K/Akt/mTOR pathway to suppress tumorigenesis and metastasis in osteosarcoma, and predicts a favorable prognosis. J Exp Clin Cancer Res 37: 188, 2018.

25. Qie S and Diehl JA: Cyclin D1, cancer progression, and opportunities in cancer treatment. J Mol Med (Berl) 94: 1313-1326, 2016.

26. Oh SJ, Cho H, Kim S, Noh KH, Song KH, Lee HJ, Woo SR, Kim S, Choi CH, Chung JY, et al: Targeting cyclin D-CDK4/6 sensitizes immune-refractory cancer by blocking the SCP3-NANOG axis. Cancer Res 78: 2638-2653, 2018.

27. Wang R, Wang J, Dong T, Shen J, Gao X and Zhou J: Naringenin has a chemoprotective effect in MDA-MB-231 breast cancer cells via inhibition of caspase-3 and -9 activities. Oncol Lett 17: 1217-1222, 2019. 
28. Shalini S, Dorstyn L, Dawar S and Kumar S: Old, new and emerging functions of caspases. Cell Death Differ 22: 526-539, 2015.

29. Guo F, Liu J, Han X, Zhang X, Lin T, Wang Y, Bai J and Han J: FBXO22 suppresses metastasis in human renal cell carcinoma via inhibiting MMP-9-mediated migration and invasion and VEGF-mediated angiogenesis. Int J Biol Sci 15: 647-656, 2019.

30. Lamouille S, Xu J and Derynck R: Molecular mechanisms of epithelial-mesenchymal transition. Nat Rev Mol Cell Biol 15: 178-196, 2014

31. Zheng X, Carstens JL, Kim J, Scheible M, Kaye J, Sugimoto H, Wu CC, LeBleu VS and Kalluri R: Epithelial-to-mesenchyma transition is dispensable for metastasis but induces chemoresistance in pancreatic cancer. Nature 527: 525-530, 2015.
32. Jie XX, Zhang XY and Xu CJ: Epithelial-to-mesenchymal transition, circulating tumor cells and cancer metastasis: Mechanisms and clinical applications. Oncotarget 8: 81558-81571, 2017.

33. Yang $\mathbf{J}$ and Weinberg RA: Epithelial-mesenchymal transition: At the crossroads of development and tumor metastasis. Dev Cell 14: 818-829, 2008.

34. Catalano M, D'Alessandro G, Lepore F, Corazzari M, Caldarola S, Valacca C, Faienza F, Esposito V, Limatola C, Cecconi F and Di Bartolomeo S: Autophagy induction impairs migration and invasion by reversing EMT in glioblastoma cells. Mol Oncol 9: 1612-1625, 2015.

35. Gugnoni M, Sancisi V, Manzotti G, Gandolfi G and Ciarrocchi A: Autophagy and epithelial-mesenchymal transition: An intricate interplay in cancer. Cell Death Dis 7: e2520, 2016. 